\title{
Hepatopancreas is the extraovarian site of vitellogenin synthesis in black tiger shrimp, Penaeus monodon
}

\author{
Deng-Yu Tseng ${ }^{\mathrm{a}}$, Ying-Nan Chen ${ }^{\mathrm{b}}$, Guang-Hsiung Kou ${ }^{\mathrm{a}}$, Chu-Fang Lo ${ }^{\mathrm{a}}$, \\ Ching-Ming Kuo ${ }^{\mathrm{c}, *}$ \\ ${ }^{a}$ Department of Zoology, National Taiwan University, Taipei, Taiwan 106, ROC \\ ${ }^{\mathrm{b}}$ Aquaculture Department, National Penghu Institute of Technology, Penghu, Taiwan 880, ROC \\ ${ }^{\mathrm{c}}$ Institute of Fisheries Science, National Taiwan University, Taipei, Taiwan 106, ROC
}

Received 6 December 2000; received in revised form 16 March 2001; accepted 19 March 2001

\begin{abstract}
The site of yolk protein synthesis in crustaceans has long been a subject of controversy. The vitellogenin gene structure was partially reported only very recently in Macrobrachium rosenbergii, after which the hepatopancreas was confirmed as the extraovarian site of vitellogenin synthesis in that species. Ovaries are the most frequently reported as the site of yolk protein synthesis in penaeid shrimp. Using cDNA reversed-transcribed from mRNA isolated from the hepatopancreas of vitellogenic female shrimp, Penaeus monodon, we found that its deduced amino acid sequence had high identity of $48 \%$ with that from M. rosenbergii vitellogenin. A similar location of the intron in the sequenced region of genomic DNA was also found between these two species. We therefore concluded that the hepatopancreas the extraovarian site of vitellogenin synthesis in P. monodon in vivo. The partial structure of vitellogenin gene is presented in this study. (c) 2001 Elsevier Science Inc. All rights reserved.
\end{abstract}

Keywords: Crustacean; Penaeid shrimp; Vitellogenesis; Vitellogenin gene; Hepatopancreas; Synthesis site; Vitellin; Genomic DNA

\section{Introduction}

Vitellogenesis, a process of hormonally regulated synthesis of yolk proteins and their subsequent deposition in ovarian oocytes, is an important reproductive process in oviparous animals. Both the site and the process of yolk protein

\footnotetext{
${ }^{*}$ Corresponding author. Present address: Department of Aquaculture, National Pingtung, University of Science and Technology, Pingtung, Taiwan 912, ROC. Tel. + 886-2-23657015; fax: + 886-2-2365-7015.

E-mail address: cmkuo@mail.npust.edu.tw (C. Kuo).
}

synthesis in crustaceans are still controversial, due to the divergent experimental methodologies employed or the species concerned. We demonstrated that the hepatopancreas is the synthesis site of vitellogenin $(\mathrm{Vg})$ in the freshwater giant prawn, Macrobrachium rosenbergii, through localization of $\mathrm{Vg}$ gene expression (Chen et al., 1999).

The yolk proteins mainly consist of $\mathrm{Vg}$ and vitellin $(\mathrm{Vn})$ in crustaceans, present, respectively, in extra-oocyte tissues and in oocytes. $\mathrm{Vg}$ and $\mathrm{Vn}$ are known to be large-molecule compounds. The complexity and heterogeneity of their structure among crustacean species are still disputable, and 
in the past, efforts have mostly been focused on determining their components and moiety. Evidence suggests that yolk proteins are lipoglycoproteins, and similarities in electrophoretic patterns and immunological reactivities between $\mathrm{Vg}$ and $\mathrm{Vn}$ were further demonstrated in several crustacean species (Zagalsky et al., 1967; Kerr, 1969; Fyffe and O'Connor, 1974 de Chaffoy de Courcelles and Kondo, 1980; Byard and Aiken, 1984; Zagalsky, 1985; Suzuki, 1987; Tom et al., 1987; Lee and Puppione, 1988; Quinitio et al., 1989, 1990; Tirumalai and Subramoniam, 1992; Chang et al., 1993a,b, 1994; Chen and Chen, 1993; Han et al., 1994; Chang and Jeng, 1995; Sagi et al., 1995; Vafopoulou and Steel, 1995; Lee et al., 1997; Qiu et al., 1997; Chen et al., 1999).

Immunohistochemical approaches and tracing of isotope-labeled amino acid incorporation in vitro have often been employed to determine the synthesis site of $\mathrm{Vg}$ in crustaceans. Ovaries, hepatopancreas, hemocytes, and fat body/adipose tissues have been reported to date as sites of $\mathrm{Vg}$ synthesis in crustaceans (Eastman-Reks and Fingerman, 1985; Yano and Chinzei, 1987; Quackenbush, 1989; Rankin et al., 1989; Suzuki et al., 1989; Browdy et al., 1990; Fainzilber et al., 1992; Shafir et al., 1992; Chen and Chen, 1994; Han et al., 1994; Vafopoulou and Steel, 1995). The ovarian tissues of penaeid shrimp were reported to be the major synthesis site of $\mathrm{Vg}$ as revealed by in vitro incubation of ovaries in the presence of labeled amino acids (Yano and Chinzei, 1987; Quackenbush, 1989; Rankin et al., 1989; Browdy et al., 1990; Fainzilber et al., 1992; Shafir et al., 1992). In Penaeus vannamei (Quackenbush, 1989) and Penaeus semisulcatus (Browdy et al., 1990), yolk synthesis in the hepatopancreas is much lower than that in ovarian tissues. However, in vivo incorporation of labeled methionine into $\mathrm{Vg}$ in female $P$. semisulcatus suggested that the hepatopancreas plays an important role in the vitellogenic process than can be deduced from in vitro studies (Shafir et al., 1992). Verification of the synthesis site of $\mathrm{Vg}$ in crustaceans requires further elucidation by considering molecular structural correlations between newly synthesized proteins and purified Vn or Vg. The localization of $\mathrm{Vg}$ mRNA will clarify the $\mathrm{Vg}$ synthesis site in vivo.

We previously reported cDNA encoding a fragment of freshwater prawn $\mathrm{Vg}$ which not only revealed the partial primary structure of $\mathrm{Vg}$ in crustaceans for the first time but also clearly demonstrated that the hepatopancreas is the site of $\mathrm{Vg}$ synthesis in $M$. rosenbergii (Chen et al., 1999). The present study is aimed at determining the site of $\mathrm{Vg}$ synthesis in the tiger shrimp, $P e$ naeus monodon, through localizing the expression of the $\mathrm{Vg}$ gene in vivo. Degenerate primers were designed according to the highly conserved domain sequences of $M$. rosenbergii Vn. RNA isolated from the ovary and hepatopancreas of vitellogenic females was employed in reverse transcription (RT). Homologies of the PCR products compared with the $\mathrm{Vg}$ gene of $M$. rosenbergii were then examined to verify the possible site of $\mathrm{Vg}$ synthesis in vivo.

\section{Materials and methods}

\subsection{Shrimp}

Naturally maturing tiger shrimp, Penaeus monodon (85-105 g in body wt.), were collected from Tunkang in southern Taiwan. The vitellogenesis of farm-reared females was induced by the unilateral eyestalk-ablation technique (Tan Fermin, 1991). Both samples were used for RNA isolation and subsequent verification of the $\mathrm{Vg}$ synthesis site in vivo.

\subsection{RNA isolation and reverse transcription (RT)}

RNA was isolated from the ovary and hepatopancreas of both naturally and induced vitellogenic female shrimp by the guanidinium thiocyanate method described by Chomczynski and Sacchi (1987). First-strand cDNA synthesis in RT was performed using a SuperScript II RNase $\mathrm{H}^{-}$ reverse transcriptase (Life Technologies, Inc., $\mathrm{MD}, \mathrm{USA})$ to transcribe poly(A) ${ }^{+}$RNA with oligo $\mathrm{d}(\mathrm{T})_{18}$ as primers. The reaction conditions recommended by the manufacturer were followed.

\subsection{Preparations of shrimp DNA}

Muscle tissue at $200 \mathrm{mg}$ excised from the abdomen of shrimp was rapidly frozen in liquid nitrogen and crushed to a fine powder. The processed tissue was placed in $2.4 \mathrm{ml}$ digestion buffer $(100$ $\mathrm{mM} \mathrm{NaCl}, 10 \mathrm{mM}$ Tris-HCl, $\mathrm{pH}$ 8, 25 mM EDTA, $\mathrm{pH} 8,0.5 \%$ sodium dodecyl sulfate, $0.1 \mathrm{mg} / \mathrm{ml}$ 
proteinase $\mathrm{K}$ ) and incubated at $65^{\circ} \mathrm{C}$ for $12-18 \mathrm{~h}$. The digest was deproteinized by successive phenol/chloroform/isoamyl alcohol extractions, recovered by ethanol precipitation, dried and resuspended in $0.1 \times \mathrm{TE}$ buffer at $65^{\circ} \mathrm{C}$ for $30 \mathrm{~min}$, and then stored at $4^{\circ} \mathrm{C}$ until use for polymerase chain reaction (PCR) (Lo et al., 1996).

\subsection{PCR and subcloning}

Based on pairwise alignments and phylogenetic comparisons between $M$. rosenbergii $\mathrm{Vg}$ amino acid sequences and other animal $\mathrm{Vg}$, primers were designed according to the highly conserved domain sequences of $M$. rosenbergii Vg. Amplification primer pairs for $P$. monodon $\mathrm{Vg}$ were as follows: forward 5'-AAGTCCCTTGGCAACATGGG-3' and reverse 5'-AGTCCTTCAAAACGTGCTCC-3'. Both genomic DNA and cDNA from vitellogenic female shrimp were used as templates in the PCR. The PCR fragments were resolved for length differences by $1.0 \%$ agarose gel electrophoresis. The amplified cDNA was cloned into the pGEM-T Easy vector using the reagents and instructions supplied by the manufacture (Promega Corporation, WI, USA). Recombinant bacteria were identified by blue/white screening and confirmed by restriction analysis. Plasmids containing the insert were purified (Promega minipreps) and used as a template for DNA sequencing. PCR reactions were performed for 30 cycles at an annealing temperature of $45^{\circ} \mathrm{C}$ for $1 \mathrm{~min}$, elongation at $72^{\circ} \mathrm{C}$ for 2 min, and denaturation at $94^{\circ} \mathrm{C}$ for $1 \mathrm{~min}$, followed by a 10 -min extension at $72^{\circ} \mathrm{C}$ and cooling to $4^{\circ} \mathrm{C}$. The PCR reaction buffer was $50 \mathrm{mM}$ Tris $-\mathrm{HCl}$ buffer (pH 9), containing $50 \mathrm{mM} \mathrm{KCl}$ and $1 \%$ Triton X-100 (Boehringer Mannheim, Germany), $2.5 \mathrm{mM} \mathrm{MgCl}_{2}, 5 \mathrm{U}$ Taq polymerase, $0.25 \mathrm{mM}$ $\mathrm{dNTPs}$, and $1 \mu \mathrm{M}$ of each primer.

\subsection{Nucleotide sequence analysis}

Nucleotide sequence analysis was performed using the dideoxynucleotide chain termination method (Sanger et al., 1977) on a DNA sequencer model 373A (Applied Biosystems, Perkin-Elmer). A sample of $1 \mu \mathrm{g}$ of plasmid DNA was used for sequencing with a Dye Terminator Cycle Sequencing Kit (Applied Biosystems, Perkin-Elmer) and was electrophoresed through $6 \%$ denaturing gels. Clones were sequenced with the M13 forward and reverse primers.

\section{Results}

Only the Macrobrachium rosenbergii $\mathrm{Vg}$ gene structure has so far been reported for crustaceans; the deduced amino acid sequence of $M$. rosenbergii $\mathrm{Vg}$ was aligned with the $\mathrm{Vgs}$ from various sources to survey the conserved domain for the purpose of primer design in the cloning of the $\mathrm{Vg}$ gene in Penaeus monodon. The alignment of amino acid sequences of $\mathrm{Vg}$ from prawn, fish, frog, chicken and nematode is shown in Fig. 1. Two highly conserved domains, KSLGNMG and GARFEGL, were therefore employed for the synthesis of forward and reverse degenerate primers and used subsequently in PCR. Total RNA isolated from the hepatopancreas of vitellogenic shrimp was used as the template for first-strand cDNA synthesis in RT. PCR products, respectively, with cDNA and genomic DNA as the templates, were electrophoresed on $1.0 \%$ agarose gel (Fig. 2). The former product was estimated to be $600 \mathrm{bp}$ from the mobility on agarose gel compared with that of a 100-bp ladder marker, and the latter was $800 \mathrm{bp}$. The nucleotide sequences of both products were determined to be 593 and 813 bp, respectively (Fig. 3). Two introns, of 101 and $119 \mathrm{bp}$, respectively, were found in this sequenced region of genomic DNA. Alignment of the deduced amino acids from P. monodon and M. rosenbergii is presented in Fig. 4. Identity between these two sequences was calculated to be $48 \%$. We consequently concluded that the hepatopancreas of $P$. monodon is a site of $\mathrm{Vg}$ gene expression. In other words, the hepatopancreas is the $\mathrm{Vg}$ synthesis site in vivo in this penaeid shrimp.

\section{Discussion}

In crustaceans, vitellin $(\mathrm{Vn})$ is generally referred to as an intraovarian yolk protein, while vitellogenin $(\mathrm{Vg})$, a yolk precursor, is an extraovarian yolk protein. The fact that $\mathrm{Vn}$ originates from Vg is widely accepted, but the transformation process of $\mathrm{Vg}$ into $\mathrm{Vn}$ is still unclear, since the molecular structures of these yolk proteins 
have not yet been elucidated. In insects, Vgs are composed of one large and one small subunit (reviewed in Kunkel and Nordin, 1985; Raikhel and Dhadialla, 1992; Valle, 1993), derived from the cleavage of a single precursor in the fat body (Bose and Raikhel, 1988; Dhadialla and Raikhel, 1990; Heilmann et al., 1993; Yano et al., 1994; Kageyama et al., 1994; Hiremath and Lehtoma, 1997), and in crustaceans, fragmentation of a larger molecule yolk protein into smaller molecules was reported for the amphipod, Orchestia gammarellus (Junera and Meusy, 1982); for the terrestrial isopods, Armadillidium vulgare (Suzuki, 1987) and Oniscus asellus (Vafopoulou and Steel, 1995); and for Penaeus vannamei (Tom et al., 1992). Reports on the Vn composition of Penaeus monodon are inconsistent to date, with supposedly four to eight polypeptides (Quinitio et al.,

(a)
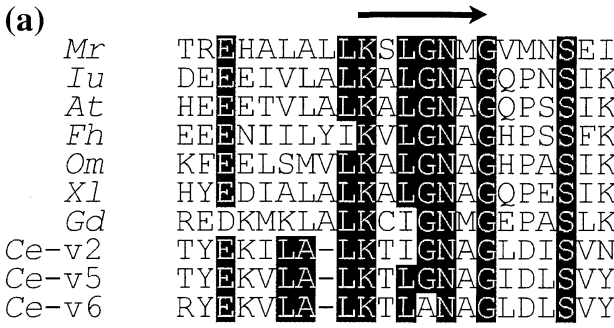

(b)
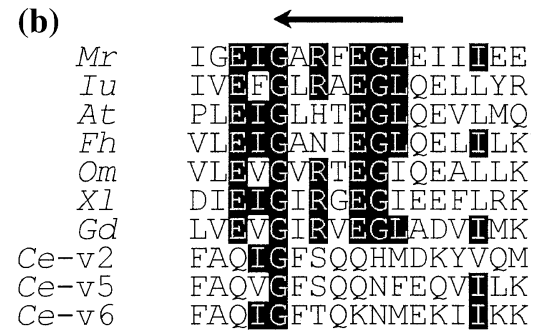

Fig. 1. Amino acid sequence alignments of two vitellogenin fragments from various animal species: freshwater giant prawn Macrobrachium rosenbergii ( $M r$ ) (Chen et al., 1999), silver lamprey Ichthyomyzon unicuspis (Iu) (Sharrock et al., 1992, GB: M88749), white sturgeon Acipenser transmontanus (At) (Bidwell and Carlson, 1995, GB: U00455), mummichog Fundulus heteroclitus (Fh) (LaFleur et al., 1995, GB: U07055), rainbow trout Oncorhynchus mykiss (Om) (LeGuellec et al., 1988, EMBL: X92804), lanuran Xenopus laevis (Xl) (GerberHuber et al., 1987, GB: M18061), chicken Gallus domesticus $(G d)$ (van het Schip et al., 1987, EMBL: X13607), and nematode Caenorhabditis elegans (Ce) (Speith et al., 1985; v2, EMBL: X56212; v5, GB: M11497; v6, EMBL: X56213). Forward and reverse primers employed were designed, based on the sequences indicated by the solid arrows.

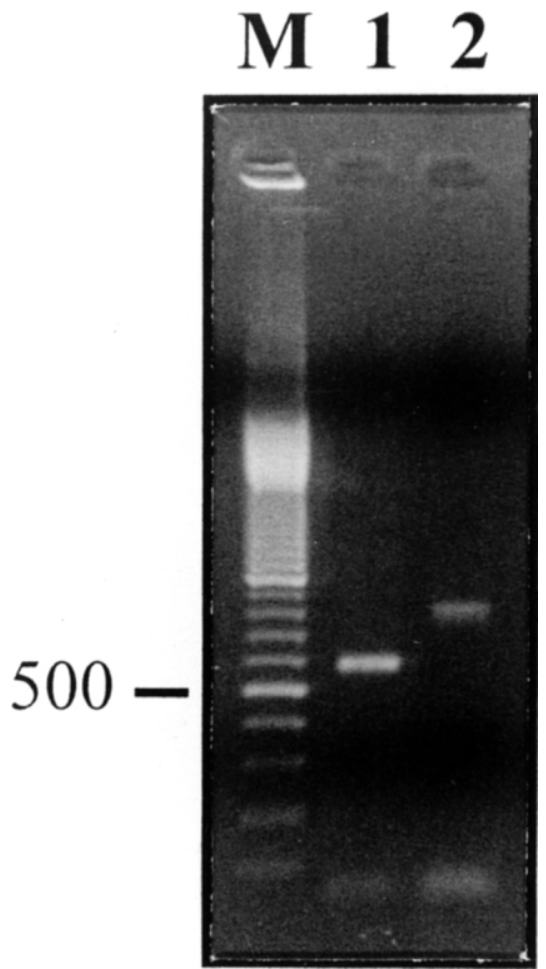

Fig. 2. Electropherogram of PCR products, respectively, using cDNA (lane 1, $593 \mathrm{bp}$ ) and genomic DNA (lane 2, $813 \mathrm{bp}$ ) as the templates. A 100-bp ladder DNA marker (M) was simultaneously electrophoresed.

1990; Chang et al., 1993a; Chen and Chen, 1993). These discrepancies are possibly due to the different methodologies employed in the process of purification and/or the different stages of ovarian development at the time of $\mathrm{Vn}$ extraction. One $\mathrm{Vn}$ in the tiger shrimp was presumed to be the yolk protein precursor, which was shown to cross-react with antisera against other components (Chen and Chen, 1993). In Macrobrachium rosenbergii, the fragmentation of yolk protein was confirmed not only from the protein level but also from the nucleotide sequences of the $\mathrm{Vg}$ gene (Chen and Kuo, 1998; Chen et al., 1999). These two major components of $\mathrm{Vn}$ are the products after post-translational modification from the same gene based on an analysis of gene sequencing.

Crustacean Vn is generally believed to be a glycolipoprotein (Zagalsky et al., 1967; de Chaffoy de Courcelles and Kondo, 1980; Zagalsky, 1985; Suzuki, 1987; Tom et al., 1987; Quinitio et al., 1990; Tirumalai and Subramoniam, 1992; Chen and Chen, 1993; Chang and Jeng, 1995; Vafopou- 


\section{(P 1 )}

1 AAG TCC CTT GGC AAC ATG GGA GTT ATT ACA CCT GCA GTA ACA AGA GCA GCA GTT GCC TGC $\begin{array}{llllllllllllllllllllll}K & S & L & G & N & M & G & V & I & T & P & A & V & T & R & A & A & V & A & C\end{array}$

ATT GAA CAA GAG GGA GTA GAA ACT AGC ATT CGA GTA GCA GCT GCA CAC GTT TTC AGA CAA $\begin{array}{llllllllllllllllllll}I & E & \& & E & G & V & E & T & S & I & R & V & A & A & A & H & V & F & R & Q\end{array}$

121 ACC AAG TGT TAT CGT CCA gta agt taa tta ctt ttt ctg ata gta gcc aac act atg aac T K C Y R P

181 cet gta ttc cta ata ctg ctg att gtt aaa tat gac taa ata tga att gaa tat ttc agG .

241 CAG TAG AGA AAC TAG TTA GTA TTG CTG TCA GAC CAG CCT TTG GAA CCG AAG TCC GTA TTG $\begin{array}{llllllllllllllllllll}A & V & E & K & \text { L } & V & \text { S } & I & A & V & R & P & A & F & G & T & E & V & R & I\end{array}$

301 CAT CGT ATC TCG CTG CCA TTA GAT GTG CAG AAA TGG AAG ATC TAG AGG AAA TCT TTG AAA $\begin{array}{llllllllllllllllllll}A & S & Y & L & A & A & I & R & C & A & E & M & E & D & L & E & E & I & F & E\end{array}$

361 AGA TCT CAG TGG AAG AGA ATA CTC AAG gtc agt att tta ctc cat agt cet tac aga tgt $\begin{array}{lllllllll}K & I & S & V & E & E & N & T & Q\end{array}$

cat caa cat cat get tag cta aaa gat ttg tat tta ctt tca tta tca cta ata ttg cag

481

atg att ata ttg aac tta cat ttc agT TCG TGG ATT TAT TCT TGG TCA CTT GCT GAA CAT

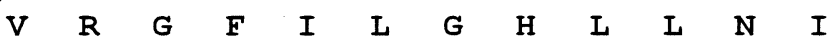

541 CCA GGA ATC TAC GTG CCC CAC CAA AGA ACA CCT CAG ATA CCT CCT GAC AAA CTT TGT GAT

$$
\begin{array}{llllllllllllllllllll}
Q & E & S & T & C & P & T & K & E & H & \text { L } & R & Y & \text { L } & \text { L } & \text { T } & \text { N } & \text { F } & \text { V } & \text { I }
\end{array}
$$

601

TCC TAT CGA TTT CGA GAG AGA CTT CAG AAA ATT CTC CCG CAA TGT GGA AAT GGC TTA TCA

$\begin{array}{lllllllllllllllllllll}P & I & D & F & E & R & D & F & R & K & F & S & R & N & V & E & M & A & Y & H\end{array}$

661 TTC TCC TTC CTT CGG CAT GGG TGG TGC TGT TGA GTC TAA CAT CAT TTA TGC TCC AGG CTC

$$
\begin{array}{llllllllllllllllllll}
S & P & S & F & G & M & G & G & A & V & E & S & N & I & I & Y & A & P & G & S
\end{array}
$$

TTT CAT TCC TCG TGC TGT TAA CTT CAA CCT AAA AGC AGA TGT AGA TGA GAC TCA TAT GGA

$\begin{array}{llllllllllllllllllll}\mathbf{F} & \mathbf{I} & \mathbf{P} & \mathbf{R} & \mathbf{A} & \mathbf{V} & \mathbf{N} & \mathbf{F} & \mathbf{N} & \mathbf{L} & \mathbf{K} & \mathbf{A} & \mathbf{D} & \mathrm{V} & \mathbf{D} & \mathbf{E} & \mathbf{T} & \mathrm{H} & \mathbf{M} & \mathbf{D}\end{array}$ (1)

781 TCT TGG CGA AAT TGG AGC ACG TTT TGA AGG ACT

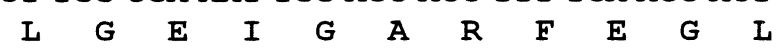

Fig. 3. The nucleotide and deduced amino acid sequences of cDNA encoding a vitellogenin fragment of tiger shrimp, Penaeus monodon. Locations of the forward and reverse primers are denoted respectively by solid and broken arrows. The specific preceding motifs for cleavage are underlined. Small letters represent the sequences of introns.

lou and Steel, 1995; Chen and Kuo, 1998). Three potential $\mathrm{N}$-glycosylation sites, NXT, were observed in the revealed $\mathrm{Vg}$ nucleotide sequences of $M$. rosenbergii (Chen et al., 1999). In contrast, no such glycosylation site in the corresponding motif of the P. monodon $\mathrm{Vg}$ gene was detected, even though Vn was identified as a glycolipoprotein (Chang et al., 1993a; Chen and Chen, 1993).
Glycosylation may be linked to the remaining domains, which remain to be sequenced.

The synthesis site of yolk proteins in crustaceans has been a subject of controversy, since the $\mathrm{Vg}$ gene sequence had not been determined and the molecular relationship between the expressed gene and translated products still remained to be elucidated. The synthesis sites so far 


\begin{tabular}{|c|c|c|}
\hline Penaeus & KSLGNMGVITPAVTR AAVACIEQEGVETSI RVAAAHVERTKCYR & 45 \\
\hline Macrobrachium & NSEIAR PILQ & 184 \\
\hline Penaeus & $\begin{array}{c}\downarrow \text { Intron } \\
-- \text { DAVEKIVSIAVR PAFGI }\end{array}$ & 87 \\
\hline Macrobrachium & $\begin{array}{l}\text { EIHPIMKQIINVILD HRKKTE } \\
\uparrow \text { Intron } \\
\downarrow \\
\downarrow \text { Intron }\end{array}$ & 229 \\
\hline Penaeus & ISVEENTQVRGEILG HLLNIQESTCPTKEH LRYLITNEVIIEIDEE & 132 \\
\hline Macrobrachium & $\begin{array}{l}\text { IAVEENTQVRSEILS HLHNVKESIATYKGN LKSKLE } \\
\uparrow \text { Intron }\end{array}$ & 274 \\
\hline Penaeus & RDFRKFSRNVEMAYH SPSEGMGGAVESNII YAPGSFIPRAVNFNI & 177 \\
\hline Macrobrachium & GAGVESNVI YAPGSYVPRSVNLNI & 319 \\
\hline Penaeus & KADVDETHMDLGEIG ARFEGL & 19 \\
\hline Macrobrachium & TAAGATPFNIGEIG ARFEGL & \\
\hline
\end{tabular}

Fig. 4. Alignment of the vitellogenin amino acid sequences from Penaeus monodon and Macrobrachium rosenbergii. Blanks, represented by dashes, are inserted to maximally align the sequences. Identical residues between these two sequences are in black reverse print.

reported include hemocytes in Callinectes sapidus (Kerr, 1968); ovarian tissues in Uca pugilator (Eastman-Reks and Fingerman, 1985), Penaeus japonicus (Yano and Chinzei, 1987), P. vannamei (Quackenbush, 1989; Rankin et al., 1989), P. semisulcatus (Browdy et al., 1990), P. monodon (Chen and Chen, 1994), and Callinectes sapidus (Lee and Watson, 1995); and fat bodies in $A r$ madillidium vulgare and Porcellio dilatatus (Picaud, 1980; Suzuki et al., 1989). In addition, the hepatopancreas of vitellogenic females is involved to some extent in vitellogenesis in P. vannamei and P. semisulcatus (Quackenbush, 1989; Shafir et al., 1992). We reported that cDNA reverse-transcribed from the mRNA isolated from a vitellogenic female hepatopancreas encoded a fragments of $\mathrm{Vg}$ in $M$. rosenbergii. That was the first time that the $\mathrm{Vg}$ gene structure was reported in crustaceans, and the synthesis site of $\mathrm{Vg}$ in vivo was also confirmed via verification of the gene expression. Following in vitro incorporation of isotope-labeled amino acids into immunoprecipitable de novo synthesis products, the ovary has been the most frequently proposed site of $\mathrm{Vg}$ synthesis in penaeid shrimp. cDNA reverse-transcribed from mRNA isolated from the hepato- pancreas of a vitellogenic female P. monodon was successfully sequenced. The identities of the deduced amino acid sequences with that of $M$. rosenbergii $\mathrm{Vg}$ were as high as $47.8 \%$. Two introns, as in $M$. rosenbergii, were further found in the correspondent region of the genomic DNA. This suggests that the hepatopancreas of $P$. monodon is an extraovarian site of $\mathrm{Vg}$ synthesis. Consequently, Vg synthesis in vivo in the hepatopancreas is apparently a common phenomenon among crustacean species.

Most insect Vgs are of the type that is cleaved in the fat body to produce two subunits. The cleavage sites are immediately preceded by a motif, $(\mathrm{R} / \mathrm{K}) \mathrm{X}(\mathrm{R} / \mathrm{K}) \mathrm{R}$ or RXXR (reviewed in Sappington and Raikhel, 1998). Indeed, a 'RQRR' motif is situated just in front of the initiation site of the $\mathrm{Vn}$ B polypeptide in $M$. rosenbergii. A similar motif, RDFR, was found in the cDNA sequence of $P$. monodon. Moreover, $(\mathrm{R} / \mathrm{K}) \mathrm{XXR}$ was revealed as the processing motif for the mammalian subtilisin-like protease family (Barr, 1991). Two such domains, KCYR and KFSR, were found in the sequences. As mentioned above, $\mathrm{Vg}$ of $P$. monodon was revealed to be composed of four to eight subunits. The cleavage in post-trans- 
lational modification seems to be more complicated than that in $M$. rosenbergii and insects. It will be helpful to clarify the possible post-translational modification process of $P$. monodon $\mathrm{Vg}$ if the sequence of full-length mRNA is determined. The composition of the $\mathrm{Vg}$ component might possibly be suggested from the location of the preceding motif in the sequences.

\section{Acknowledgements}

This research was supported by the National Science Council, Republic of China to CMK (grant no. NSC89-2611-B-002-001).

\section{References}

Barr, P.J., 1991. Mammalian subtilisins: the long-sought diabasic processing endoproteases. Cell 66, 1-3.

Bidwell, C.A., Carlson, D.M., 1995. Characterization of vitellogenin from white sturgeon (Acipenser transmontanus). J. Mol. Evol. 41, 104-112.

Bose, S.G., Raikhel, A.S., 1988. Mosquito vitellogenin subunits originate from a common precursor. Biochem. Biophys. Res. Commun. 155, 436-442.

Browdy, C.L., Fainzilber, M., Tom, M., Loya, Y., Lubzens, E., 1990. Vitellin synthesis in relation to oogenesis in in vitro-incubated ovaries of Penaeus semisulcatus (Crustacea, Decapoda, Penaeidae). J. Exp. Zool. 255, 205-215.

Byard, E.H., Aiken, D.E., 1984. The relationship between molting, reproduction, and a hemolymph female-specific protein in the lobster, Homarus americanus. Comp. Biochem. Physiol. A 77, 749-757.

Chang, C.-F., Jeng, S.-R., 1995. Isolation and characterization of the female-specific protein (vitellogenin) in mature female hemolymph of the prawn Penaeus chinensis. Comp. Biochem. Physiol. B 112, 257-263.

Chang, C.-F., Lee, F.-Y., Huang, Y.-S., 1993a. Purification and characterization of vitellin from the mature ovaries of prawn, Penaeus monodon. Comp. Biochem. Physiol. B 105, 409-414.

Chang, C.-F., Shih, T.-W., Hong, H.-H., 1993b. Purification and characterization of vitellin from the mature ovaries of prawn, Macrobrachium rosenbergii. Comp. Biochem. Physiol. B 105, 609-615.

Chang, C.-F., Lee, F.-Y., Huang, Y.-S., Hong, T.-H., 1994. Purification and characterization of the female-specific protein (vitellogenin) in mature female hemolymph of the prawn, Penaeus monodon. Invert. Reprod. Dev. 25, 185-192.

Chen, C.-C., Chen, S.-N., 1993. Isolation and partial characterization of vitellin from the egg of the giant tiger prawn Penaeus monodon. Comp. Biochem. Physiol. B 106, 141-146.

Chen, C.-C., Chen, S.-N., 1994. Vitellogenesis in the giant tiger prawn, Penaeus monodon Fabricius 1789. Comp. Biochem. Physiol. B 107, 453-460.

Chen, Y.-N., Kuo, C.-M., 1998. Purification and characterization of vitellin from the freshwater giant prawn, Macrobrachium rosenbergii. Zool. Stud. 37, 126-136.

Chen, Y.-N., Tseng, D.-Y., Ho, P.-Y., Kuo, C.-M., 1999. Site of vitellogenin synthesis determined from a cDNA encoding a vitellogenin fragment in the freshwater giant prawn, Macrobrachium rosenbergii. Mol. Reprod. Dev. 54, 215-222.

Chomczynski, P., Sacchi, N., 1987. Single-step method of RNA isolation by acid guanidinium thiocyanatephenol-chloroform extraction. Anal. Biochem. 162, 156-159.

de Chaffoy de Courcelles, D., Kondo, M., 1980. Lipovitellin from the crustacean, Artemia salina. J. Biol. Chem. 255, 6727-6733.

Dhadialla, T.S., Raikhel, A.S., 1990. Biosynthesis of mosquito vitellogenin. J. Biol. Chem. 265, 9924-9933.

Eastman-Reks, S.B., Fingerman, M., 1985. In vitro synthesis of vitellin by the ovary of the fiddler crab, Uca pugilator. J. Exp. Zool. 233, 111-116.

Fainzilber, M., Tom, M., Shafir, S., Applebaum, S.W., Lubzens, E., 1992. Is there extraovarian synthesis of vitellogenin in penaeid shrimp? Biol. Bull. 183, 233-241.

Fyffe, W.E., O'Connor, J.D., 1974. Characterization and quantification of a crustacean lipovitellin. Comp. Biochem. Physiol. B 47, 851-867.

Gerber-Huber, S., Nardelli, D., Haefliger, J-A. et al., 1987. Precursor-product relationship between vitellogenin and the yolk proteins as derived from the complete sequence of a Xenopus vitellogenin gene. Nucleic Acids Res. 15, 4737-4760.

Han, C.-H., Okumura, T., Suzuki, Y., Aida, K., Hanyu, I., 1994. Immunocytochemical identification of the site of vitellogenin synthesis in the freshwater prawn Macrobrachium nipponense. Fisheries Sci. 60, 149-154.

Heilmann, L.J., Trewitt, P.M., Kumaran, A.K., 1993. Proteolytic processing of the vitellogenin precursor in the boll weevil, Anthonomus grandis. Arch. Insect. Biochem. Physiol. 23, 125-134.

Hiremath, S., Lehtoma, K., 1997. Complete nucleotide sequence of the vitellogenin mRNA from the gypsy moth: novel arrangement of the subunit encoding regions. Insect. Biochem. Mol. Biol. 27, 27-35.

Junera, H., Meusy, J.-J., 1982. Vitellogenin and lipovitellins in Orchestia gammarellus (Pallas) (Crustacea, Amphipoda); labelling of subunits after in vivo administration of ${ }^{3} \mathrm{H}$-leucine. Experientia 38, 252-254. 
Kageyama, Y., Kinoshita, T., Umesono, Y., Hatakeyama, M., Oishi, K., 1994. Cloning of cDNA for vitellogenin of Athalia rosae (Hymenoptera) and characterization of the vitellogenin gene expression. Insect. Biochem. Mol. Biol. 24, 599-605.

Kerr, M.S., 1968. Protein synthesis by hemocytes of Callinectes sapidus: a study of in vitro incorporation of ${ }^{14}$ C-leucine. J. Cell. Biol. 39, 72a-73a.

Kerr, M.S., 1969. The hemolymph proteins of the blue crab, Callinectes sapidus: II. A lipoprotein serologically identical to oocyte lipovitellin. Dev. Biol. 20, 1-17.

Kunkel, J.G., Nordin, J.H., 1985. Yolk proteins. In: Kerkut, G.A., Gilbert, L.J. (Eds.), Comprehensive Insect Physiology, Biochemistry and Pharmacology. Pergamon Press, Oxford, pp. 83-111.

LaFleur Jr., G.J., Byrne, B.M., Kanungo, J., Nelson, L.D., Greenberg, R.M., Wallace, R.A., 1995. Fundulus heteroclitus vitellogenin: the deduced primary structure of a piscine precursor to noncrystalline, liquid-phase yolk protein. J. Mol. Evol. 41, 505-521.

Lee, C.-Y., Watson, R.D., 1995. In vitro study of vitellogenesis in the blue crab (Callinectes sapidus): site and control of vitellin synthesis. J. Exp. Zool. 271, 364-372.

Lee, F.-Y., Shin, T.-W., Chang, C.-F., 1997. Isolation and characterization of the female-specific protein (vitellogenin) in mature female hemolymph of the freshwater prawn, Macrobrachium rosenbergii: comparison with ovarian vitellin. Gen. Comp. Endocrinol. 108, 406-415.

Lee, R.-F., Puppione, D.L., 1988. Lipoproteins I and II from the hemolymph of the blue crab Callinectes sapidus: lipoprotein II associated with vitellogenesis. J. Exp. Zool. 248, 278-289.

LeGuellec, L.K., Kenneth, L.Y., Martin, T., 1988. Vitellogenin gene expression in male rainbow trout. Gen. Comp. Endocrinol. 71, 359-371.

Lo, C.-F., Leu, J.-H., Ho, C.-H. et al., 1996. Detection of baculovirus associated with white spot syndrome (WSBV) in penaeid shrimps using polymerase chain reaction. Dis. Aquat. Org. 25, 133-141.

Picaud, J.L., 1980. Vitellogenin synthesis by the fat body of Porcellio dilatatus Brandt (Crustacea, Isopoda). Invert. Reprod. Dev. 2, 341-349.

Qiu, Y.-W., Ng, T.-B., Chu, K.-H., 1997. Purification and characterization of vitellin from the ovaries of the shrimp Metapenaeus ensis (Crustacea: Decapoda: Penaidae). Invert. Reprod. Dev. 31, 217-223.

Quackenbush, L.S., 1989. Vitellogenesis in the shrimp, Penaeus vannamei: in vitro studies of the isolated hepatopancreas and ovary. Comp. Biochem. Physiol. B 94, 253-261.

Quinitio, E.T., Hara, A., Yamauchi, K., Mizushima, T., Fuji, A., 1989. Identification and characterization of vitellin in a hermaphrodite shrimp, Pandalus kessleri. Comp. Biochem. Physiol. B 94, 445-451.

Quinitio, E.T., Hara, A., Yamauchi, K., Fuji, A., 1990. Isolation and characterization of vitellin from the ovary of Penaeus monodon. Invert. Reprod. Dev. 17, 221-227.

Raikhel, A.S., Dhadialla, T.S., 1992. Accumulation of yolk proteins in insect oocytes. Annu. Rev. Entomol. 37, 217-251.

Rankin, S.M., Bradfield, J.Y., Keeley, L.L., 1989. Ovarian protein synthesis in the south American white shrimp, Penaeus vannamei, during the reproductive cycle. Invert. Reprod. Dev. 15, 27-33.

Sagi, A., Soroka, Y., Snir, E., Chomsky, O., Calderon, J., Milner, Y., 1995. Ovarian protein synthesis in the prawn Macrobrachium rosenbergi: does ovarian vitellin synthesis exist? Invert. Reprod. Dev. 27, 41-47.

Sanger, F., Nicklen, S., Coulson, A.R., 1977. DNA sequencing with chain-terminating inhibitors. Proc. Natl. Acad. Sci. USA 74, 5463-5467.

Sappington, T.W., Raikhel, A.S., 1998. Molecular characteristics of insect vitellogenins and vitellogenin receptors. Insect. Biochem. Mol. Biol. 28, 277-300.

Shafir, S., Ovadia, M., Tom, M., 1992. In vivo incorporation of labeled methionine into protein, vitellogenin, and vitellin in females of the penaeid shrimp Penaeus semisulcatus de Haan. Biol. Bull. 183, 242-247.

Sharrock, W.J., Rosenwasser, T.A., Gould, J., Hussey, D., Gordon, J.I., Banazak, L., 1992. Sequence of silver lamprey vitellogenin: implications for lipovitellin crystal structure. J. Mol. Biol. 226, 903-907.

Speith, J., Denison, K., Zucker, E., Blumenthal, T., 1985. The nucleotide sequence of a nematode vitellogenin gene. Nucleic Acids Res. 13, 7129-7138.

Suzuki, S., 1987. Vitellins and vitellogenins of the terrestrial isopod, Armadillidium vulgare. Biol. Bull. 173, 345-354.

Suzuki, S., Yamasaki, K., Katakura, Y., 1989. Vitellogenin synthesis by fat body and ovary in the terrestrial isopod, Armadillidium vulgare. Gen. Comp. Endocrinol. 74, 120-126.

Tan Fermin, J.D., 1991. Effects of unilateral eyestalk ablation on ovarian histology and oocyte size frequency of wild and pond-reared Penaeus monodon fabricius broodstock. Aquaculture 93 (1), 77-86.

Tirumalai, R., Subramoniam, T., 1992. Purification and characterization of vitellogenin and lipovitellins of the sand crab Emerita asiatica: molecular aspects of crab yolk proteins. Mol. Reprod. Dev. 33, 16-26.

Tom, M., Goren, M., Ovadia, M., 1987. Purification and partial characterization of vitellin from the ovaries of Parapenaeus longirostris (Crustacea, Decapoda, Penaeidae). Comp. Biochem. Physiol. B 87, 17-23. 
Tom, M., Fingerman, M., Hayes, T.K., Johnson, V., Kerner, B., Lubzens, E., 1992. A comparative study of the ovarian proteins from two penaeid shrimps, Penaeus semisulcatus de Haan and Penaeus vannamei (Boone). Comp. Biochem. Physiol. B 102, 483-490.

Vafopoulou, X., Steel, C.G.H., 1995. Vitellogenesis in the terrestrial isopod, Oniscus asellus (L.): characterization of vitellins and vitellogenins and changes in their synthesis throughout the intermolt cycle. Invert. Reprod. Dev. 28, 87-95.

Valle, D., 1993. Vitellogenesis in insects and other groups-a review. Mem. Inst. Oswaldo. Cruz. 88, 1-26.

van het Schip, F., Samallo, J., Bross, J., Ophuis, J., Mojet, M., Gruber, M., 1987. Nucleotide sequence of a chicken vitellogenin gene and derived amino acid sequence of the encoded yolk precursor protein. J. Mol. Biol. 196, 245-260.
Yano, I., Chinzei, Y., 1987. Ovary is the site of vitellogenin synthesis in Kuruma prawn, Penaeus japonicus. Comp. Biochem. Physiol. B 86, 213-218.

Yano, K., Sakurai, M.T., Watabe, S., Izumi, S., Tomino, S., 1994. Structure and expression of mRNA for vitellogenin in Bombyx mori. Biochim. Biophys. Acta 1218, 1-10.

Zagalsky, P.F., 1985. A study of the astaxanthin-lipovitellin, ovoverdin, isolated from the ovaries of the lobster, Homarus gammarus (L.). Comp. Biochem. Physiol. B 80, 589-597.

Zagalsky, P.F., Cheesman, D.F., Ceccaldi, H.J., 1967. Studies on carotenoid-containing lipoproteins isolated from the eggs and ovaries of certain marine invertebrates. Comp. Biochem. Physiol. 22, 851-871. 